\title{
DRÓN IRÁNYÍTÁSI PROBLÉMA LOGISZTIKAI KÖZPONTBAN
}

\author{
Gubán Ákos \\ tanszékvezető főiskolai tanár, Budapesti Gazdasági Egyetem, PSZK, Gazdaságinformatika Tanszék \\ 1149 Budapest, Buzogány utca 10.-12., e-mail: guban.akos@uni-bge.hu
}

Udvaros József

Adjunktus, Budapesti Gazdasági Egyetem, PSZK, Gazdaságinformatika Tanszék

1149 Budapest, Buzogány utca 10.-12., e-mail: udvaros.jozsef@uni-bge.hu

\begin{abstract}
Absztrakt
Egy nagy Közép-Európai logisztikai központ, mely más multinacionális cégek számára biztosít raktározási, komissiózási, elosztási és szállítmányozási szolgáltatásokat új innovatív megoldásokat keres. A cég több nagyméretü raktárral is rendelkezik egy szlovákiai ipari parkban. A készletellenörzési rendszer jelenleg komoly emberi eröforrást igényel és emellett nagyon sok idöt vesz igénybe, ezáltal ritkán rendelkeznek a készletekröl és raktározási megoldásaikról valós idejü információkkal. Ezért a készletek automatikus vizsgálatára drón alkalmazása vetödött fel, melynek pilot verziója már tesztelés alatt van. Ellenben két nagyon komoly probléma merült fel a tesztek során: az elsö problémát az okozza, hogy a raktár Faraday kalitkaként müködik, így a GPS jelek nem jutnak be, A másik probléma a drón mozgatásra rendelkezésre álló energiájának maximális kihasználása. Ezért egy optimális útvonaltervezésre is szükség van. A cikkben ezekre a problémákra keresünk megoldási javaslatokat.
\end{abstract}

Kulcsszavak: drón, logisztikai központ, logisztika, raktározási megoldás

\begin{abstract}
A large Central European logistics center that provides warehousing, picking, distribution and forwarding services to other multinational companies looking for new innovative solutions. The company also has several large warehouses in an industrial park in Slovakia. The inventory control system currently requires serious human resources and takes a lot of time, rarely having real-time information about inventory and storage solutions. For this reason, drone application has been introduced for automatic scanning of stocks, and the pilot version is already being tested. However, two very serious problems were encountered during the tests: the first problem is that the warehouse functions as a Faraday cage, so the GPS signals do not get in.. Another problem is to maximize the power of the drone available for moving. This also requires optimum route planning. We are looking for solutions to these problems in this article.
\end{abstract}

Keywords: drone, logistics center, logistics, storage solutions

\section{Bevezetés}

A logisztikai elosztóközpontok, decentrumok, illetve szolgáltató centrumok raktárrendszere egyre nagyobb alapterületű és magasságú raktárbázisokon végzik tevékenységüket. Ráadásul nagyobb mennyiségü, valamint eltérő termékek és egységrakományok be-, és kitárolását, raktározását kell elvégezniük, mindezeket változó időtartamban. A gyors áruforgás miatt a valós készletnyilvántartás igen bonyolulttá válik, sokszor a nyilvántartási és valós adatok eltérnek, emiatt szükséges az aktuális kész- 
let rendszeres ellenőrzése. Mindezen feladatok hagyományosan manuálisan történő összevetése még a konzumerizált és smart eszköz világában is nagyon nehézkes és lassú folyamat. A probléma megoldására több megoldás is létezik, mely megoldásokat a raktárak szerkezete mérete nagyban befolyásol. A vizsgálatunkban egy logisztikai központ két nagy alapterületü raktárral rendelkezik $(62.000 \mathrm{~m} 2$, $55.000 \mathrm{~m} 2$ ) a raktárakban egy egyszeres mélységü ötszintes (teljes magasságú polc esetén) polcrendszer található, amelyben a polcmagassága felezhető esetleg harmadolhatók. Egy polcon három egységrakomány helyezhető el, valamint minden egymás melletti polc között egy kisebb távolság található.

A készlet ellenőrzését egy professzionális drón segítségével oldjuk meg, melynek feladata minden egyes polcon lévő egységrakomány beazonosítása és összevetése a nyilvántartási adattal, jeleznie kell, hogy a megfelelő áru a megfelelő helyen található, egyáltalán az áru fellelhetö-e. Ezt a problémát vizsgáljuk meg abból a szempontból, mennyire küszöbölhető ki az emberi beavatkozás, milyen bejárási útvonala javasolható, figyelembe véve a drón véges energia ellátását.

Ilyen fajta megoldásokat már több helyen alkalmaznak elsősorban multinacionális nagy vállalatok esetében. Sok nagyon jó megoldás ismert, mint Hardis Group által kifejlesztett Eyesee rendszer, mely egy átfogó drónleltár-megoldás, amely magában foglalja a pilóta nélküli repülésre képes drónt, és amely vonalkódadatok automatikus rögzítésére és azonosítására szolgáló rendszerrel van ellátva és az adatokat az Amazon Web Services keresztül kezeli. [10]

\section{Kapcsolódó szakirodalmak}

Az Amazon, a DHL és a Workhorse, sok más társaság között, intenzíven tanulmányozzák, hogy a drónok miként alkalmazhatók szállítási tevékenységekre. Ez az új technológia ösztönözte számos matematikai modell és megoldási módszer kifejlesztését erre a problémára, hozzájárulva a kis légi jármüvek áruk szállításakor történő lehetséges elönyeinek elemzéséhez. Különösen a drónok és a teherautók közötti együttmüködés az üzemeltetés napján javíthatja az utolsó mérföldre történő szállítást, mivel az útvonalakat idő- és költségmegtakarítás szempontjából hatékonyabban lehet megtervezni.

David Sacramento [4] a cikkében egy matematikai modellt fogalmaznak meg, amely meghatározza az „utazó eladó problémájához” hasonló problémát, de a több nagy kapacitással ellátott teherautó esetében, időkorlátozással és minimalizálva a költségeket objektív függvényként. Mivel a nagy példányok optimális megoldása nehéz, az adaptív nagy szomszédsági keresési metaheurisztikát javasolják. Végül kiterjedt számítási kísérleteket végeznek. A tesztek többek között azt vizsgálják, mennyire előnyös a drón-kézbesítési lehetőség beépítése, összehasonlítják azzal az esettel, hogy minden tárgyat kizárólag teherautókkal szállítsanak. Ezen felül részletes érzékenységi elemzést végeznek számos érdeklődésre számot tartó drónparaméternél.

Az [5] azzal a problémával foglalkozik, hogy több, pilótanélküli légi jármü számára megtalálják az útvonalakat, amelyek együttmüködési misszió végrehajtására szolgálnak, kommunikációt, koordinációt és helyzet-ismereteket igényelnek. Ezért olyan térbeli és időbeli korrelációval járó pályákat részesítenek előnyben, amelyekben egy mutatót javasolnak a pályák közötti diszperzió mérésére. Ezt a diszperziós mutatót használják a minimális diszperziós útválasztási probléma objektív függvényében. Egy keresési genetikai algoritmust módszerként javasolnak az új útválasztási probléma megoldására, és ezt a megközelítést módosított referencia jármü-útválasztási problémapéldányok segítségével kipróbálták. Számítási eredményeik azt mutatják, hogy a megközelítés nagyon sikeres, és a diszperzió szempontjából kívánt jellemzőkkel bíró pályákat eredményez.

A [6] cikkben a gépjármü útvonal problémát vizsgálja meg a drónok segítségével (VRPD, The Vehicle Routing Problem with Drones), amelyekben teherautók drónokat is szállítanak. A drónt a te- 
herautó szállíthatja, elvonulhat az ügyfelek kiszolgálása érdekében, és leszállhat egy szervizközpontban egy másik teherautóval történő szállításhoz, feltéve, hogy a repülési távolság és a teherbírási korlátozások teljesülnek. A teherautók és a drónok útvonal tervezési és integrált irányítási problémája sokkal nagyobb kihívást jelent és különbözik a klasszikus VRP irodalomtól. A VRPD számára egy ív alapú egész programozási modellt javasolnak. Mivel a speciális problémaszerkezet számos korlátozást eredményez, újra formáljak azt útirányú modellként, és kidolgozzák az elágazás és árazási algoritmust. Az árazási alprobléma során olyan speciális hálózatot terveztek, amely megkülönbözteti a különféle útvonalakat és csomópontokat, és továbbfejlesztett impulzus algoritmust mutatnak be testreszabott metszés és kiterjesztési stratégiák révén. Az oszlopgeneráció lassú konvergenciájából származó célhatás enyhítése érdekében kiszámolják az alternatív Lagrange alsó határértéket és alkalmazzák az oszlopgenerációs stabilizációt.

Az elágazási és az árazási algoritmus segítségével az optimális megoldásokat egy példánykészletre kapják, a Gurobi MIP megoldója 20 példányból 19 példányra optimális megoldást nyújt. Az átlagos költségkülönbség meghaladja a 6\%-ot a Gurobi által megvalósítható megoldások és az optimális megoldások között. A VRP-megoldással összehasonlítva a VRPD-megoldás nemcsak átlagosan 20\%-ot takarít meg, hanem minden vásárló átlagosan 5 perccel csökkenti a szállítási időt, ami bizonyítja a drónok kézbesítésének hatékonyságát. Az érzékenység elemzésében megfigyelték, hogy egy fejlett akkumulátor technika, amely megkétszerezi a drónok repülési idejét, közel 10\%-kal csökkenti a logisztikai költségeket.

A [7]-ben bemutatják a VRPDERO-t (The Vehicle Routing Problem with Drones and En Route Operations), amely több teherautó és drón kombinációjából áll, egy utolsó mérföldes szállítási környezetben. A VRPDERO és a VRPD közötti szignifikáns különbség az, hogy az előbbi lehetővé teszi a drónok indítását és a jármüvek által ívekben történő visszajutását; pontosabban, a drónok indítását és begyüjtését az egyes ív egyes különálló lépésein lehet engedélyezni. A VRPDERO-t vegyes egész számú lineáris programként fogalmazták meg. Ezután javasolják az érvényes egyenlőtlenségeket a megoldó teljesítményének javítása érdekében, és számítási kísérletekkel megmutatják az érvényes egyenlőtlenségek hatékonyságát. A Gurobi Optimizer segítségével azonban csak néhány kisebb léptékủ problémát tudunk optimálisan megoldani ésszerủ futási időn belül. Ezért bevezettek egy heurisztikát, amely a változtatható szomszédsági keresés és a tabu keresés fogalmain alapul. Ezen heurisztika keretein belül, mint egy helyi keresési operátor, bevezettek egy drone beillesztési eljárást, amelyet beépítettek a megosztó és meghódító megközelítésbe. Átfogó számítási tanulmányt nyújtottak be, amely számos problémaparaméter hatását vizsgálta, például a gyártási időre és a futási időre nézve.

\section{A probléma vázolása}

Drónnal történő készletnyilvántartásra több megoldást is kínálnak cégek. A vizsgálatunkban egy nagy logisztikai szolgáltató cég egy szlovákiai decentrumának készletezési problémáját vizsgáljuk. Jelenleg tesztelés alatt van egy drónnal történő készletfigyelési rendszer. A probléma vázolása érdekében az alábbi fogalmakat fogjuk használni az 1. ábrán jelölteknek megfelelően: 


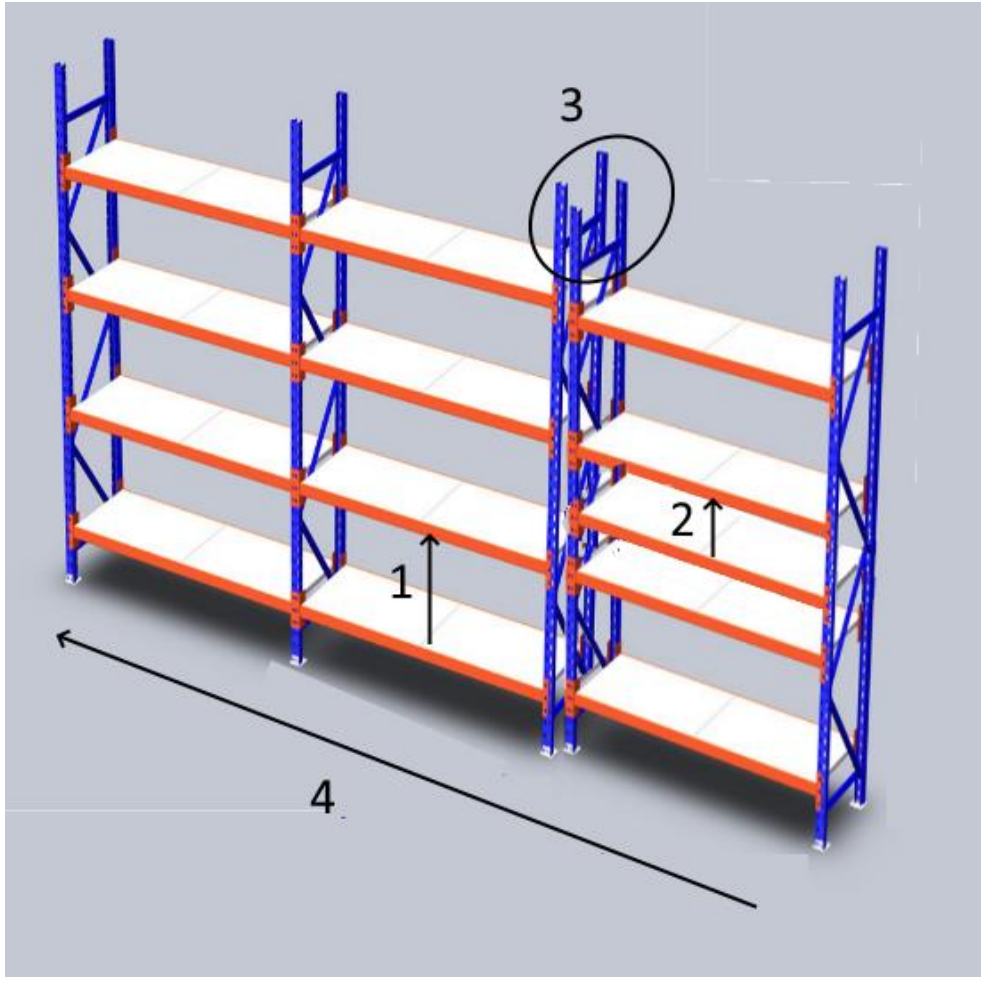

1. ábra. Általános fogalmak (saját szerkesztésü ábra)

1. polc

2. rekesz

3. (polc) elválasztó

4. sor

A teszt során az alábbi problémákat tapasztaltuk:

1. Az első probléma a manuális beavatkozás szükségessége esetleg ideális esetben a teljesen automatikus müködés megvalósítása. Ezt a problémát az okozza, hogy a vizsgált raktár Faraday kalitkaként müködik, így sem a GPS sem pedig a Galileo jelek nem jutnak be, ezáltal a drón nem vezérelhetö GPS-pozíción keresztül. Emiatt a pozícionálás csak és kizárólag a drón mozgásának nyomkövetésével oldható meg. Az alkalmazott drón közelségérzékelő szenzort, giroszkópot, kamerát, GPS vevőt tartalmaz. Azaz minden müködési időpillanatban ismernünk kell a drón a térbeli sebességvektorának irányát és irányítását, valamint a nagyságát. Továbbá probléma, hogy figyelembe kell venni a gyorsítást és lassítást. Szükség van mindhárom koordinátára, hiszen a drón akkumulátorkapacitás kihasználás szempontjából fontos a függőleges és vízszintes mozgás figyelése. A gondot a drón mozgásának egyedisége okozza. Nehezíti a helyzetet az, hogy az üres rekeszek esetén nincs megállás és indulás (mivel a drón rendelkezik távolság érzékeléssel, ezen képessége alapján a drón tudja, hogy üres a rekesz) ezért ezeken gyorsabban keresztülhalad, továbbá mozgást igényel a nem üres rekeszek a QR kód érzékelése, 
fotózása érdekében történő közelítő, távolító mozgás, amely miatt a drón polcrendszer vízszintes irányú sebességvektora kisebb lesz az elvártnál.

2. A polcokon elhelyezett egységrakományokon egy QR kódazonosító szerepel legalább egy méter magasságban, melyet a rendszernek azonosítani (szkennelni) és értelmezni kell tudnia. Ez csak úgy oldható meg hiba nélkül, ha a drón a megtalálás után megáll és a streamelt képfolyamban elöállít olyan képet, amit kezelő eszköz (tablet) szkenner szoftvere értelmezni tud. Az üres rekeszeket fel kell ismernie a rendszernek és itt nincs megállás. Továbbá fontos megjegyezni az egységrakományok behelyezéskor kismértékben eltérő mélységben kerülnek be a polc helyekre.

3. A harmadik probléma a drón útvonal optimalizálása, ez azért fontos, mert célszerü egy „repülés" alatt a lehető legtöbb rekesz (polc) azonosítása és feldolgozása. Ez nem feltétlen a legrövidebb utat jelenti. Lehetséges, hogy a legrövidebb út során nagyon sok irányváltást kell tenni, sok lesz a lassítás, forgás és gyorsítás esetleg emelkedés mindezek nagymértékben növelik a drón energia felvételét, ezáltal csökkenti a „levegőben” töltött időt.

A fenti problémák megoldása fontos a logisztikai decentrum számára. Jelen cikkünkben az első kettő (összefüggnek) felvetésre keresünk megoldási lehetőséget.

\section{Módszertan}

Az első, amit vizsgálni kell a drón mozgatása és tárgy felismerése - a mi esetünkben QR kód felismerés. Ehhez hasonló problémát elemez [1] az ő általuk vizsgált probléma, egy meghatározott zárt területen mozgó drónnak a célkövetése - ez túlmutat a mi problémánkon, mivel a cél felismerése és a sebesség megválasztása a céljuk, ezek lefedik a mi érdeklődési körünket. A cikk a Fuzzy megoldást választja, ami számunkra is egy járható út lesz, hiszen sok esetben a QR kód pozíciója az adott lokáción belül nem egyértelmü és a kamerája sajnos nem minden esetben lát rá. Emiatt számunkra is az alap és determinisztikus mozgás után szükséges lesz egy fuzzy vezérlés. Ezt alkalmazhatjuk az oszlopokból eredő eltérések esetén is. [2] irodalom számunkra egy használható megoldást mutatnak be, bár ez kisebb hardver befektetést igényel, a cikkben GPS mentes környezetben a drón pozícionálását a robotikában, önvezetésben alkalmazott ToF kamera alkalmazásával oldja meg. A kamerát a mennyezetre szerelték fel és ez végzi el a drón $\mathrm{x}, \mathrm{y}$ irányú pozícionálását és a magasság változását. Itt fontos technikai megoldásokat mutatnak be, kivédik a rotorok által keltett interferenciás zavarokat. Az általuk megadott Gauss függvényre alapuló szürés miatt képes 3D-ben pontos helyzetelemzésre. A cikk pontos algoritmust is ad megoldásként. Egy másik megfontolásra érdemes módszertan mutat be zárt területü drón vezérlésre a [3] irodalom. A szerzők voxel modellt alkalmaznak, és kétféle útszámítást végeznek, egyik a legrövidebb útra vonatkozik, a másik a legolcsóbb utat számítja. A problémájuk elsősorban akadályelkerülés képelemzés segítségével, erre felhasználja A. Rosenfeld, J. L. Pfaltz, Distance functions on digital pictures, Pattern Recogn. [9] alapmüben lefektetett (elsőként ök javasolták) abnormális képre javasolt a távolság-transzformáció módszert. A mi problémánk esetében az akadályokat a polcok adják, ezt a jelenlegi megoldásban fixen definiáltnak tételezik fel, ami problémás, hiszen változhat. Megoldásaikban biztonságos, de hatékonysági távolságon belül tartja a drónt az akadálytól. Egy másik cikk keresést javasol ismert pályaútvonal lehetőségek között [8]. Javaslatukban egy használható genetikus algoritmust alkalmaz, ez nagyon használható lenne a mi számunkra az optimális bejárási útvonal megválasztásában. A kezdeti populációt egy véletlen generálású mohó algoritmussal választja ki.

Számunkra a fenti megoldások sokat segítenek, de nem adnak az adott lehetőségekhez megfelelő megoldást. 
A Fuzzy és GA megoldások viszont nagy segítséget nyújthatnak megoldásainkban. A pontos helyzetmeghatározáshoz 3D mozgás alapján próbálunk beltéri helyzetet meghatározni, ez azért jó, mert a sebesség változást diszkréten tudjuk kezelni, az adott mért pozíciók közötti átlagsebességet tekintve. A mozgást két komponensből építjük fel, egyrészt egy determinisztikus mozgásból és egy kontrollált mozgásból.

\section{Probléma modellje}

A polcrendszer adatai röviden összefoglalva a következök.

Háromféle méretü lokáció van: $210 \mathrm{~cm}$ (full), $140 \mathrm{~cm}$ (3/4) és $100 \mathrm{~cm}$ (half) magas (ez a kereszttartót beleszámítva, amire a paletta van elhelyezve). Minden lokáció $97 \mathrm{~cm}$ szeles (átlagosan a polcrendszer lábait beleszámolva).

A polcrendszer vertikális elosztása nagyon változik az 5 teljes es a 9 fél között. Vannak sorok melyek végig egyformák, de vannak, ahol polconként változik. Egy polcba 3 paletta fér el, igy legalább 3 paletta egy magasságban helyezkedik el.

A szomszéd polc vertikális elosztása már más is lehet. les).

Egy utcában (vízszintes sorban) 101 paletta helyezkedik el (31 polc + 2 átjáró, amely 4 paletta szé-

A problémát elöször kezeljük egy 2D problémának, azaz tekintsünk egy polcsort. Ez persze nem jelenti azt, hogy nem kell függőlegesen is mozognia, hiszen a QR kódok eltérő magassága, illetve az osztott polcok függőleges mozgást igényelnek. Továbbá élünk azzal az egyszerüsítéssel a kezdeti modellben, hogy a QR kód a rekeszfelező magasságából visszakódolható (felismerhető).

Legyen D; $n$ dimenziós vektor, ahol $n$ az adott sorban lévő polcok szám, és $\mathbf{H} n \times m$ mátrix, mely a polcon belüli rekeszek száma.

D $(i)$ jelentse az $i>1$ rekesz jobb szélének távolságát a $i-1$-től. Ezek az adatok a logisztikai szolgáltató központ adatbázisába elhelyezhetők, a bejárást a jobbról-balra irányítjuk.

$\mathbf{H}(i ; j)$ jelentse, hogy az $i$ polc oszlop, $j$ polca hány rekeszt tartalmaz, konkrét esetben ez 1-4 közötti természetes szám lehet. A szerepe, hogy az adott polcon kell-e függőleges mozgást végezni QR kód elérése érdekében. A 2. ábra ezt szemlélteti.

Továbbá:

- egy teljes polcmagasság legyen $h$,

- a polcszélességet jelölje $d$,

- $\quad k$ legyen a polcrendszerben függőlegesen elhelyezkedő teljes polcok száma,

- $s$ az első polc szintjének magassága,

- $\quad l$ a polcrendszerben lévő polcoszlopok száma. 


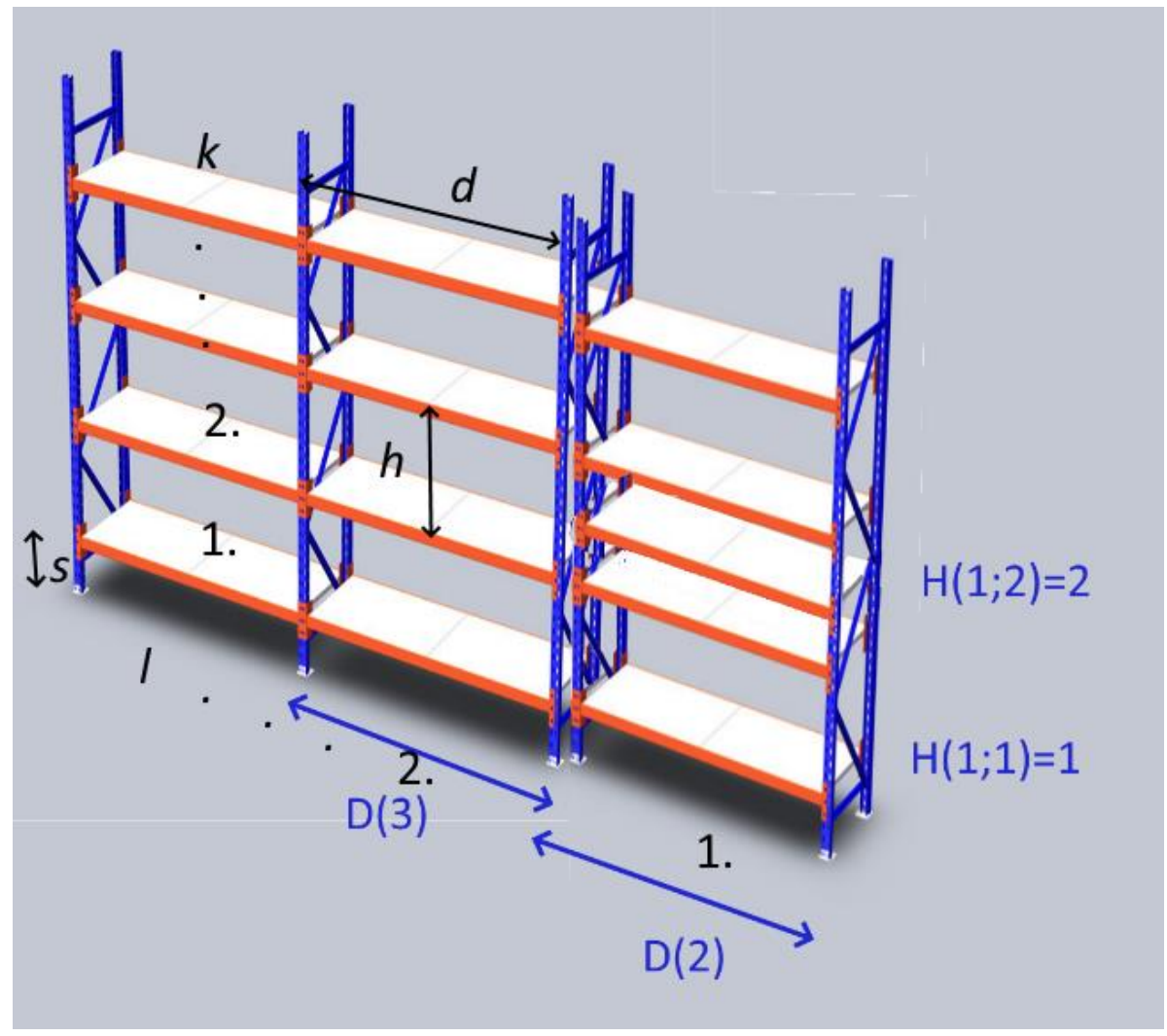

2. ábra. Modell elemek jelentése (saját szerkesztés)

A drón mozgását egy folyosóban célszerü a legfeleső szinttől indítani, mivel ideális esetben így csupán egyszer kell emelkednie. A sorok végén csupán ereszkedést kell végrehajtani, ami sokkal energia kímélőbb megoldás.

Az eljárásban a drón a polcrendszer jobb szélén, a padlószinten helyezkedik el. Első mozgatás egy függőleges emelkedés, mégpedig a legfelső szint rekeszének magasságközéppontjába, a polc szélén.

$$
H_{1}=s+(k-1) h+\left\{(\mathbf{H}(1 ; k)-1)+\frac{1}{2}\right\} \frac{h}{\mathbf{H}(1 ; k)}
$$

A komponensek: padlószinttől való eltérése az első polcnak, az adott polcoszlopban a polcszámnak megfelelö emelkedés, valamint a legfelső polc rekeszei közül a legfelső pozícionálása.

A függőleges pozíció így behatárolható. A kérdés az, hogy hová pozícionáljon a drón vízszintesen? Sajnos teljesen bizonytalan, hogy hová teszik a QR kód címkét, ez csupán a munkás kényelmétől függ. Ezért el kell indítani balra a drónt, és figyelni milyen sebességgel haladva ismeri fel a QR kódot, figyelembe véve a felgyorsítást a QR kódig megtett horizontális hossz ( $\delta$ távolság):

$$
\delta=\frac{a}{2} t_{1}^{2}+a t_{1} t_{2}+\Delta t\left(a t_{1}\right)
$$


ahol $t$ a QR kódig történő repülés ideje, $t_{1}$ a gyorsítás ideje, $t_{2}$ a polc végéig eljutás ideje.

$$
t_{2}=\left\{\begin{array}{c}
\left(t-t_{1}\right) \text { ha } t>t_{1} \\
0 \text { különben }
\end{array}\right.
$$

valamint a $\Delta t\left(a t_{1}\right)$ mely a drón sebességéből származó QR kód felismerési tehetetlenségi távolság. A mozgatásra ezek után kétféleképpen van lehetőség, attól függően, hogy milyen az aktuális polckiosztás és mi a szomszédos polc kiosztása. Amennyiben az aktuális $i$ és $i+1$ polcokra érvényes $\mathbf{H}(i+1 ; j)=$ $\mathbf{H}(i ; j)$ akkor célszerü $\mathbf{D}(i+1)$ vízszintes mozgást végrehajtani, ha $i+1 \leq l$.

Amennyiben a két feltétel közül valamelyik nem teljesül és $i+1>l$ akkor csökkentést kell végrehajtani, mégpedig ha nem a legalsó sorban vagyunk, akkor a alatta lévő polc legfelső rekeszénék középső magassági pozíciójába, könnyen számítható. Amennyiben a másik feltétel nem teljesül, azaz nem értünk a folyosó végére, és egy szélesebb polcoszlophoz értünk, akkor a mozgást annak a távolságnak megfelelően kell felezve a fenti mozgással pozícionálni.

Látszólag egyszerünek tünik a fenti eljárás, mégsem lehet - ebben a raktárban - teljes hiba nélkül alkalmazni. Egyrészt a nem teljesen megbízható gyorsulási és lassulási feltételek miatt, másrészt a tehetetlenség miatt, illetve harmadrészt a QR kód esetleges elhelyezés miatt. Próbateszt alapján, egységes QR kód felrakás során, nagyon kevés kézi hangolást igényelt a drón (bár így is igényelt).

Megállapítható, mindaddig pontos automatikus pozícionálás a jelenlegi drón típussal nem valósítható meg, amíg nem rendezhető egységesen a polcrendszer, illetve a QR kód felragasztása nem egy jól meghatározott módon történik.

\section{6. Összefoglalás, javaslat}

A probléma elemzése, modellezése közben az nyilvánvalóvá vált, hogy a jelenlegi logisztikai megoldások és az alkalmazott drón mellett nem oldható meg a készletgazdálkodás folyamatának automatizációja. Javaslatainkat az alábbiakban foglaljuk össze.

1. Az egységrakományokra elhelyezett QR kódokat egy jól meghatározott szabványos helyre lenne célszerü elhelyezni, ennek pozícióját a rakomány jobb alsó sarkától kellene meghatározni mindkét irányba. Ennek helyét esetleg egy lézeres mutatóval, vagy magára a csomagolóeszközre rajzolni (mivel bérraktározásról van szó ez utóbbi nehezen valósítható meg).

2. A polcrendszerre megfelelő szakaszonként (függőlegesen és vízszintesen is egy vonalkódos azonosítót kellene elhelyezni, ami javítaná a pozicionálást és az oszlopra vonatkozó alapinformációk is kezelhetők lennének.

3. Ez a javaslatunk magasabb költséggel jár, de nagyon növelné a hatékonyságot: ToF kamerák alkalmazása esetén pontos helymeghatározásban és a mozgási irányokban is segítenének.

4. Ez utóbbi is akkor lenne hatékony, amennyiben több felhasználható szenzorral ellátott „,profi” drón(ok) kerülnének alkalmazásra. (Típusukra, illetve a szenzorok fajtáira, a gyors fejlődés miatt nem adunk ebben a cikkben javaslatokat.) A drónnal szembeni elvárások: hosszú müködési idő, pontos giroszkópos helymeghatározás, valós idejủ sebesség visszajelzés, a kamerája biztosítson mozgás közben is pontos kódolvasást.

Összefoglalva, sikerült javítani az útvonalbejárást, a drón kapacitásának jobb kihasználását, valamint egy kezelő segítségével, félautomata megoldást biztosítani a jelenlegi helyzetre és a megoldás sokkal hatékonyabb, mint a korábban alkalmazott „,szemrevételezéses” megoldás. 


\section{Irodalom}

[1] Jácome, R.N., Huertas, H.L., Procel, P.C., Garcés, A.G. Fuzzy Logic for Speed Control in Object Tracking Inside a Restricted Area Using a Drone, Smart Innovation, Systems and Technologies 2020, 152:135-145. https://doi.org/10.1007/978-981-13-9155-2_12

[2] Álvarez, J., Aguilera, T., Arand, F.J. Precise drone location and tracking by adaptive matched filtering from a top-view ToF camera, Expert Systems with Applications 2020, 141:112989. https://doi.org/10.1016/j.eswa.2019.112989

[3] Li, F., Zlatanova, S., Koopman, M., Bai, X., Diakité, A. Universal path planning for an indoor drone, Automation in Construction 2018, 9:275-283. https://doi.org/10.1016/j.autcon.2018.07.025

[4] Sacramento, D., Pisinger, D., Ropke. S.: 2019. An adaptive large neighborhood search metaheuristic for the vehicle routing problem with drones. Transportation Research Part C 2019, 102:289-315. https://doi.org/10.1016/j.trc.2019.02.018

[5] Dhein, G., Zanetti, M.S., de Araújo, O.C.B., Cardoso Jr, G. Minimizing dispersion in multiple drone routing. Computers and Operations Research 2019, 109:28-42. https://doi.org/10.1016/j.cor.2019.04.022

[6] Wang, Z., Sheu, J.-B. Vehicle routing problem with drones. Transportation Research Part B 2019, 122:350-364. https://doi.org/10.1016/j.trb.2019.03.005

[7] Schermer, D., Moeini, M., Wendt. O. A hybrid VNS/Tabu search algorithm for solving the vehicle routing problem with drones and en route operations. Computers and Operations Research 2019, 109:134-158. https://doi.org/10.1016/j.cor.2019.04.021

[8] Dhein, G., Zanetti, M.S., de Araújo, O.C.B., Cardoso Jr, G. Minimizing dispersion in multiple drone routing, Computers \& Operations Research 2019, 109:28-42. https://doi.org/10.1016/j.cor.2019.04.022

[9] Rosenfeld, A., Pfaltz, J.L. Distance functions on digital pictures, Pattern Recogn. (1968) https://doi.org/10.1016/0031-3203(68)90013-7

[10] https://eyesee-drone.com/eyesee-the-inventory-drone-solution/ (letöltés 2020.03.10) 